Images in...

\title{
Rectus sheath haematoma
}

\author{
Hameem I Kawsar, ${ }^{1}$ Jamila Shahnewaz, ${ }^{2}$ Hardik Bhansali, ${ }^{1}$ Hamed Daw ${ }^{2}$ \\ ${ }^{1}$ Fairview Hospital, Cleveland, Ohio, USA \\ ${ }^{2}$ Cleveland Clinic Cancer Center, Cleveland, Ohio, USA
}

Correspondence to Dr Hamed Daw, hdaw2000@yahoo.com

\section{DESCRIPTION}

A 64-year-old Caucasian man with a history of smoking, chronic obstructive pulmonary disease (COPD), hypertension and diabetes mellitus presented with increasing shortness of breath and cough. While being treated for COPD exacerbation, he developed atrial fibrillation with rapid ventricular response. Treatment with intravenous diltiazem was started. Serum electrolyte levels, twodimensional echocardiogram and thyroid function tests were normal. Antiplatelet therapy with subcutaneous enoxaparin was initiated. After the first dose, he complained of gradually worsening lower abdominal pain. A complete blood count showed decreased haemoglobin and coagulation studies was normal. He gradually developed a small swelling in the right supra-pubic area, which was tender to palpation. Both Fothergill and Carnett's signs were positive. An abdominal ultrasonogram showed a $14.4 \times 4.7 \times 5.5 \mathrm{~cm}$ cystic mass with fluid levels in the right lower quadrant of the rectus sheath (figure 1, arrow). Enoxaparin was stopped and he was treated conservatively. A follow-up CT scan of the

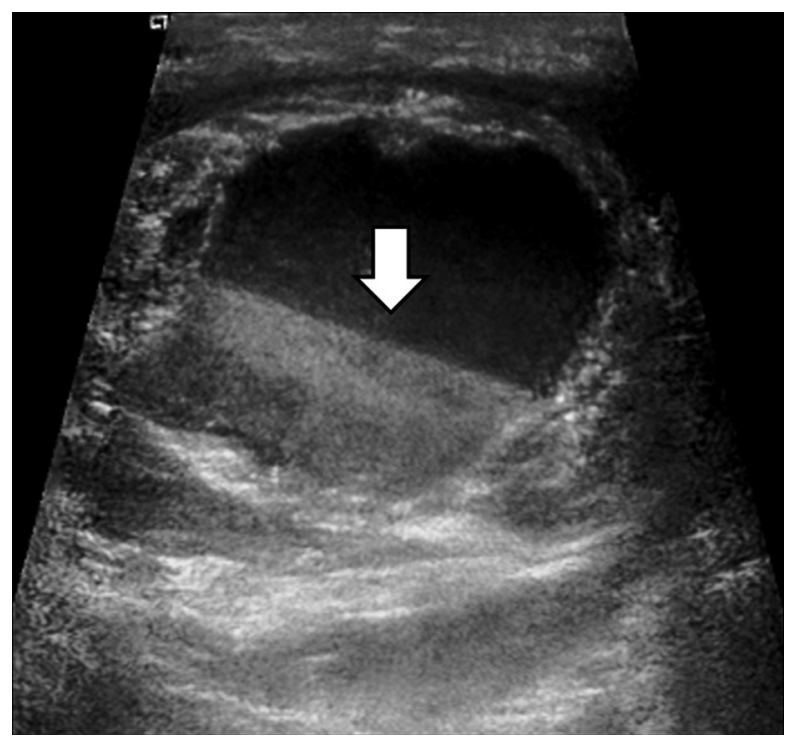

Figure 1 An ultrasonogram of the anterior abdominal wall.

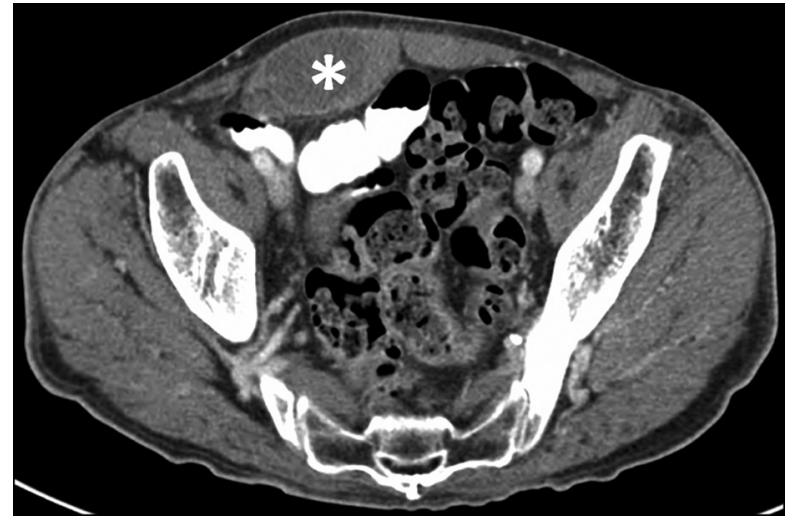

Figure 2 A CT scan of the abdomen.

abdomen showed a right rectus sheath haematoma (RSH; figure 2, asterisk).

$\mathrm{RSH}$ results from bleeding into the rectus sheath, frequently due to anticoagulation. Clinical examination helps to differentiate between abdominal wall and retroperitoneal haematoma. ${ }^{1}$ Ultrasonography is $85-96 \%$ and CT scan is $100 \%$ sensitive in diagnosing RSH. RSH is usually managed conservatively but surgical intervention is warranted if the patient is unstable or conservative treatment fails. ${ }^{2}$

Learning points

- Rectus sheath haematoma can be life threatening if diagnosis and management is delayed.

- High clinical suspicion along with imaging studies (ultrasonogram, CT scan) can help prompt diagnosis.

Competing interests None.

Patient consent Obtained.

\section{REFERENCES}

1. Suleiman S, Johnston DE. The abdominal wall: an overlooked source of pain. Am Fam Physician 2001;64:431-8.

2. James RF. Rectus sheath hematoma. Lancet 2005;365:1824. 


\section{BMJ Case Reports}

This pdf has been created automatically from the final edited text and images.

Copyright 2012 BMJ Publishing Group. All rights reserved. For permission to reuse any of this content visit http://group.bmj.com/group/rights-licensing/permissions.

BMJ Case Report Fellows may re-use this article for personal use and teaching without any further permission.

Please cite this article as follows (you will need to access the article online to obtain the date of publication).

Kawsar HI, Shahnewaz J, Bhansali H, Daw H. Rectus sheath haematoma. BMJ Case Reports 2012;10.1136/bcr.02.2012.5909, Published XXX

Become a Fellow of BMJ Case Reports today and you can:

- Submit as many cases as you like

- Enjoy fast sympathetic peer review and rapid publication of accepted articles

- Access all the published articles

- Re-use any of the published material for personal use and teaching without further permission

For information on Institutional Fellowships contact consortiasales@bmjgroup.com

Visit casereports.bmj.com for more articles like this and to become a Fellow 